\title{
Can the preterm lung recover from perinatal stress?
}

Matthias C. Hütten ${ }^{1,2,3,4}$, Tim G. A. M. Wolfs ${ }^{1,4}$ and Boris W. Kramer ${ }^{1,4^{*}}$

\begin{abstract}
After birth, adequate lung function is necessary for the successful adaptation of a preterm baby. Both prenatal and postnatal insults and therapeutic interventions have an immediate effect on lung function and gas exchange but also interfere with fetal and neonatal lung development. Prenatal insults like chorioamnionitis and prenatal interventions like maternal glucocorticosteroids interact but might also determine the preterm baby's lung response to postnatal interventions ("second hit") like supplementation of oxygen and drug therapy. We review current experimental and clinical findings on the influence of different perinatal factors on preterm lung development and discuss how wellestablished interventions in neonatal care might be adapted to attenuate postnatal lung injury.
\end{abstract}

Keywords: Lung injury, Chorioamnionitis, Glucocorticosteroids, Caffeine, Oxygen toxicity, Ventilation, Bronchopulmonary dysplasia, Vitamin A

\section{Introduction}

The lung function of a preterm baby is key to the successful adaptation after birth since no gas exchange via diffusion will be possible without sufficient maturity of the alveolar and capillary unit [1]. The development of the fetal lung is affected by antenatal maternal glucocorticoids, chorioamnionitis, and maternal nutrition [2]. Altered fetal development affects pulmonary responses after birth to subsequent-postnatal-injuries such as oxygen toxicity or responses to drugs [3]. The different effects of antenatal and postnatal insults and interventions are summarized in Fig. 1. In this review, we will give a concise overview of recent developments on lung function and growth that highlight the interaction between factors that determine lung plasticity in the context of lung injury, regeneration, and immunomodulation and in the development of bronchopulmonary dysplasia (BPD).

\section{Chorioamnionitis as prenatal insult}

The exposure to microbes in utero appears to be very common in preterm deliveries [4]. Chorioamnionitis induced by different microbial triggers results in pulmonary

\footnotetext{
*Correspondence: b.kramer@maastrichtuniversity.nl

${ }^{1}$ Neonatology, Department of Pediatrics, Maastricht University Medical Center, Maastricht, Netherlands

${ }^{4}$ Faculty of Health, Medicine and Lifesciences, School for Oncology and Developmental Biology, Maastricht University, Maastricht, The Netherlands Full list of author information is available at the end of the article
}

inflammation and subsequent structural simplification in the alveoli and vasculature of the fetal lung $[5,6]$. In the clinical course of postnatal pulmonary adaptation and development in preterm infants, chorioamnionitis plays a dual role. On the one hand, exposure to chorioamnionitis might protect preterm infants from respiratory distress syndrome (RDS) [7]. In animal models, prenatal exposure to inflammatory stimuli supported surfactant production and structural maturation and resulted in better lung compliance [8]. However, surfactant replacement therapy has been shown to be less effective in preterm infants who were exposed to chorioamnionitis and developed a fetal inflammatory response [9]. Moreover, data from experimental models show that lung injury after exposure to intrauterine inflammation depends among others on the type of the infectious agents and the time of onset of intrauterine inflammation [3]. This might explain the inconsistent effect of chorioamnionitis on postnatal pulmonary adaptation. On the other hand, growing evidence suggests an important role of intrauterine inflammation as contributing factor to the development of BPD [10-12]. Animal experiments revealed that intrauterine inflammation resulted in structural lung impairment [13] and disturbance of developmental pathways in the lung, impairing growth factors and branching morphogenesis [6]. These long-term effects might also depend on the severity of the inflammatory response. In a recent clinical 


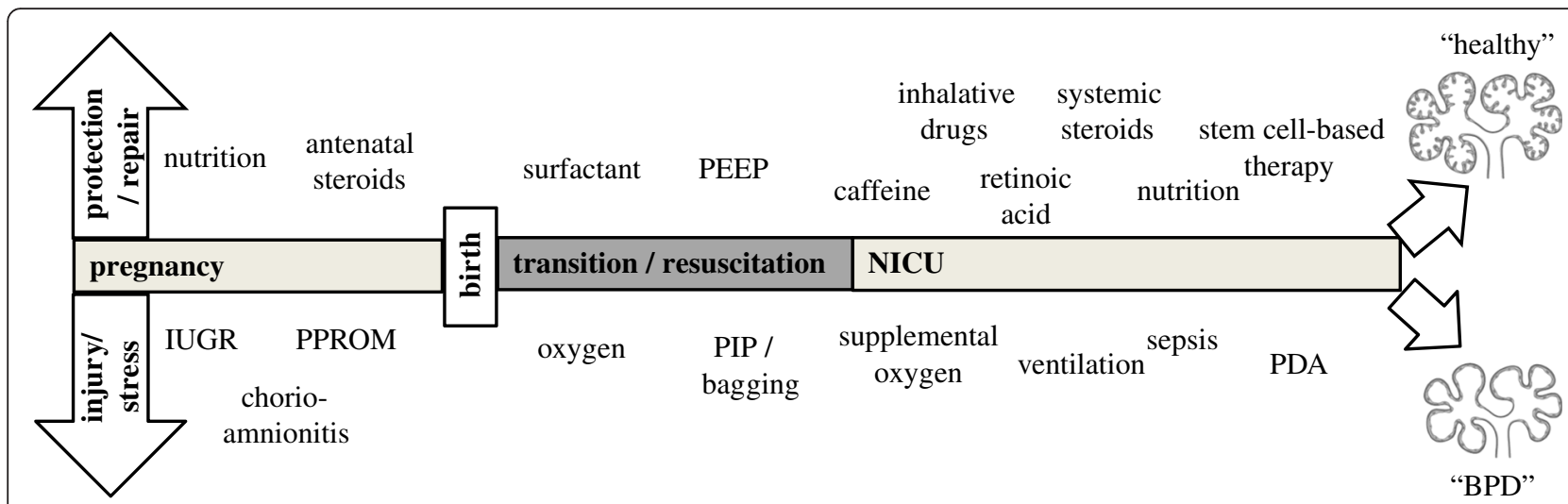

Fig. 1 Multiple factors influence lung development in preterm infants. Postnatally, both potentially protective and injurious factors are mainly associated with therapeutic means. IUGR intra-uterine growth restriction, PPROM preterm premature rupture of membranes, PIP positive inspiratory pressure, PEEP positive end-expiratory pressure, PDA persistent ductus arteriosus, NICU neonatal intensive care unit, BPD

bronchopulmonary dysplasia

study, histological severity of fetal inflammation in cases of chorioamnionitis was independently associated with development of BPD, even after adjusting for gestational age [14]. Moreover, preexposure to chorioamnionitis alters inflammatory reaction on a second inflammatory stimulus [15]. Fetal attenuated reaction on repeated inflammatory stimuli can prevent lung injury [16]; therefore, the association between prenatal inflammation and postnatal lung injury remains complex.

\section{Chorioamnionitis and antenatal corticosteroids-combined effects}

The course and the time point of onset of infection are-in cases of clinically silent chorioamnionitis-not to be determined [17]. In cases of clinical chorioamnionitis, the maternal symptoms suggest the onset of a maternal response to microbes which does not preclude the use of antenatal maternal steroids [18]. Antenatal maternal corticosteroid therapy accelerates fetal lung maturation [19] and supports endogenous surfactant production [20]. Although there is an ongoing discussion about the ideal preparation and dosing [21], maternal glucocorticosteroids are the gold standard treatment when premature delivery is expected [22]. However, experimental data revealed that the combined effects of prenatal exposure to chorioamnionitis and glucocorticosteroids are variable and do not simply "add up". The time point of administration of antenatal steroids before or after the onset of chorioamnionitis in a sheep model of LPS-induced chorioamnionitis was studied in order to assess the effects of lung maturation and immune modulation in a preclinical model [23]. Inhibition or even prevention of impaired structural pulmonary development appeared to be dependent on the timing of administration of maternal steroids [24, 25]. Administration before onset of LPS-induced chorioamnionitis reduced pulmonary inflammation [25], counteracted LPS-induced transforming growth factor $\beta$ (TGF $\beta$ ) pathway activation [23], and prevented structural changes [24]. Pulmonary inflammation was not attenuated if administration of maternal glucocorticoids was done after onset of chorioamnionitis, and inflammatory cells in the lung increased [25]. In contrast, positive effects of maternal glucocorticoids on lung function and surfactant metabolism were enhanced when they were given after onset of pulmonary inflammation [25]. These findings emphasize that the mechanisms linking intrauterine inflammation to the induction of lung structural changes are multi-factorial [6].

One possible link is oxidative stress, with BPD being considered as an oxygen-radical disease of the preterm [26]. Chorioamnionitis has multiple effects on levels of reactive oxygen species and enzymes involved in the detoxification of reactive oxygen species. However, these effects are not invariably positive or negative. Data obtained in the preclinical lamb model of chorioamnionitis shows that acute intrauterine inflammation precedes increases in oxidants in the fetal airways [27] but also increases in antioxidant enzyme activity in fetal lung tissue [28]. Taken together, the effect of chorioamnionitis on oxidative stress in the lung still needs to be elucidated. In addition, it is unclear whether chorioamnionitis leads to antenatal conditioning of fetal redox systems which may affect the response to a pre- or postnatal second hit [29-31]. For example, modulation of fetal oxidative stress has been reported after maternal glucocorticoid administration in both experimental $[32,33]$ and clinical settings [34-36], but it remains unclear if these effects vary depending on the presence or absence of inflammation. Moreover, inflammation can also result from oxidative stress [37], which highlights the role of oxygen toxicity as risk factor for adverse neonatal outcomes [31]. 


\section{Postnatal interventions-oxygen}

The fetus develops in a low oxygen environment, and the arterial partial pressure of oxygen $\left(\mathrm{PaO}_{2}\right)$ physiologically rises directly after birth [38]. This abrupt change in oxygen content of blood and tissue may induce physiological maturation of metabolic processes after birth [39]. However, an excess supply of oxygen resulting in hyperoxia might have detrimental effects on infants born prematurely. Oxygen supplementation is one of the most common therapeutic interventions in resuscitation of newborns [40]. However, its historically generous use in the delivery room has been abandoned in the last years due to new evidence from clinical studies [41]. In the ground breaking Resair 2 study by Saugstad et al., the authors showed that resuscitation of term babies after asphyxia could efficiently be performed with room air instead of $100 \%$ oxygen [42].

In preterm infants, current guidelines advocate the use of a mixture of air and oxygen according to the infants' oxygen saturation $\left(\mathrm{SpO}_{2}\right)$. These are based on the observation that an increase in oxygenation after birth is a gradual process [43]. A recent meta-analysis of studies comparing different initial fractions of oxygen $\left(\mathrm{FiO}_{2}\right)$ in delivery room stabilization and resuscitation of preterm infants $\leq 32$ weeks showed a trend towards a lower mortality when the initial $\mathrm{FiO}_{2}$ was $0.21-0.30$ [44]. Two studies found a significant increase of markers of oxidative stress in preterm infants resuscitated with 90-100\% oxygen compared to 21 or $30 \%$ [45, 46]. These findings indicate a possible mechanism how supplemental oxygen contributes to lung injury of preterm infants in the context of prenatal abnormalities, variables like positive pressure ventilation during transition and perinatal resuscitation and postnatal insults [47].

Therefore, current guidelines recommend using an initial $\mathrm{FiO}_{2}$ of $0.21-0.30$ and to subsequently titrate $\mathrm{FiO}_{2}$ according to the infant's $\mathrm{SpO}_{2}$ measured by pulse oximetry in order to avoid hyperoxia [48-50]. $\mathrm{SpO}_{2}$ measurement in preterm infants within the first minutes of life is feasible [51], and it is supposed to replace color as the traditional parameter for oxygenation [49]. However, aiming at variable $\mathrm{SpO}_{2}$ target values within the first $10 \mathrm{~min}$ of life is difficult, and large deviations from $\mathrm{SpO}_{2}$ targets during resuscitation of preterm infants have been observed in clinical studies [52], suggesting that manual $\mathrm{FiO}_{2}$ control in the delivery room is inadequate. A possible solution is the use of automated closed loop $\mathrm{FiO}_{2}$ control, which has been proven to efficiently keep infants within a predefined $\mathrm{SpO}_{2}$ target in the NICU, using various modes of ventilation, and using different algorithms (as reviewed in [53]). Although automated $\mathrm{FiO}_{2}$ control has not yet been tested in the delivery room setting in clinical trials [54], we could show in a lamb model of preterm respiratory distress syndrome that closed-loop $\mathrm{FiO}_{2}$ control is feasible during the transition after birth and during surfactant replacement therapy [55]. Moreover, automated $\mathrm{FiO}_{2}$ control during transition in the first $15 \mathrm{~min}$ of life resulted in less hyperoxia in our model [55]. Automated $\mathrm{FiO}_{2}$ control might therefore become a key element in balancing oxygen supplementation and in avoiding complications associated with early oxygen over- or underexposure.

\section{Mechanical ventilation as first or second hit}

Oxygen therapy in the delivery room is regularly combined with manual inflations ("bagging"), ventilatory support with continuous positive airway pressure (CPAP), or mechanical ventilation. "Opening" the liquid-filled lung directly after birth in order to increase inspiratory volume and functional residual capacity (FRC) is a prerequisite for sufficient gas exchange. However, this early intervention can have lasting effects on the preterm lung. Experimentally, bagging of preterm lambs compromised the beneficial effect of surfactant replacement therapy [56]. Sustained lung inflation (SLI) increased FRC [57] but caused a modest increase of proinflammatory cytokines in the lungs of preterm lambs [58]. In a recent clinical trial, SLI did not decrease the occurrence of BPD in preterm infants born between 25 and 28 weeks and 6 days compared to a control group [59]. In this study, the need for mechanical ventilation within the first 3 days of life was decreased but not the overall need for respiratory support [59]. Experimentally, mechanical ventilation of preterm lambs increased inflammation and impaired developmental signaling in the lungs $[60,61]$. However, mechanical ventilation might interact with prenatal factors. Prolonged mechanical ventilation increased the risk of BPD in a clinical study, and this effect was stronger when chorioamnionitis was present [11]. In contrast, antenatal betamethasone decreased lung injury but not lung inflammation in a preterm lamb model of resuscitation with escalating tidal volumes [62]. Avoidance of mechanical ventilation can be reached by utilizing CPAP with [63] or without [64] surfactant replacement therapy. Recently published data from the German neonatal network confirmed that surfactant replacement therapy in spontaneously breathing infants was associated with lower rates of mechanical ventilation and BPD [65]. Understanding the interaction between respiratory support and prenatally acquired preconditions might further help to minimize stress in the preterm lung.

\section{Caffeine-early and late effects on the lung}

In the context of hypoxia, apnea of prematurity is widely recognized as a key problem in infants born prematurely. It has been successfully treated in the last three decades with methylxanthines, especially caffeine [66]. Caffeine is 
used both prophylactically and therapeutically, and a third indication is weaning from an endotracheal tube [67].

Although earlier trials had raised concerns about unwanted side effects like increased oxygen consumption and impaired weight gain [68], recent clinical trials showed impressive short-term and long-term beneficial effects of caffeine treatment in preterm infants [69]. In the Caffeine for Apnea of Prematurity (CAP) trial, the duration of positive pressure ventilation was shortened and supplemental oxygen could be stopped earlier in VLBW infants receiving caffeine instead of placebo as secondary outcome [67]. In the caffeine group, removal of endotracheal tube was possible at an earlier gestational age, and the need for postnatal steroids was significantly lower [67]. In line with these findings, a Cochrane review described less failure of extubation in infants receiving prophylactic methylxanthines (odds ratio $0.48,95 \% \mathrm{CI}$, 0.32-0.71) [70].

More interestingly, the CAP trial could show that caffeine reduced BPD, defined as need for supplemental oxygen at 36 weeks corrected gestational age, from 47 to $36 \%$ [67]. This effect is presumably linked to the shortened duration of positive pressure respiratory support. However, a recent retrospective study revealed a strong correlation between high serum levels of caffeine and a decreased incidence of BPD in infants born $\leq 29$ weeks GA [71]. These findings might result from a dose dependency of the beneficial effects of caffeine on lung function parameters and respiratory muscle strength [72]. Alternatively, preventive effect of caffeine for BPD might be linked to the anti-inflammatory effects on cytokine profiles of preterm babies which have been described recently [73], opening a promising field for future research.

Moreover, data from both the CAP trial and from retrospective cohort studies indicate how important timing of the start of caffeine therapy might be. In a subgroup analysis of the CAP trial, infants in whom caffeine therapy was initiated early, i.e., $<3$ days of age, had a significantly lower postmenstrual age at last endotracheal intubation and last positive pressure ventilation [74]. This suggests a possible mechanism for the decrease in BPD rates in infants receiving caffeine $<3$ days of age in two retrospective studies probably through less mechanical ventilation $[69,75]$. However, early respiratory improvement might also be linked to additional therapeutic effects of caffeine. Caffeine is a known inhibitor of phosphodiesterase, and the consecutive bronchodilation by an increase of cyclic AMP might support the infants' respiration [76]. In addition, experimental data suggest that caffeine amplifies the positive effect of prenatal glucocorticosteroids on surfactant-protein $B$ expression, indicating a maturational effect of caffeine on the preterm lung [77]. In vitro, an additive effect on both transcription and translation of SP$\mathrm{B}$ was shown [78]. This effect was confirmed in in vivo studies in spontaneously breathing preterm lambs born to ewes that received glucocorticoids. The preterm lambs received immediately after birth intravenous caffeine citrate and were maintained on CPAP. At the end of the study, the secreted SP-B in the bronchoalveolar lavage was several fold higher than in controls without caffeine [77]. However, although these findings suggest caffeine administration within the first hours of life or even in the delivery room as useful, the results of currently ongoing clinical trials [79] are needed to develop future recommendations.

\section{Pharmacological support of lung recovery and development-vitamin A}

Drugs for postnatal modulation of lung injury have been extensively studied in the past. One of the most promising substances is vitamin A. Vitamin A is crucial for fetal lung development and maturation and prerequisite for adequate lung development $[80,81]$. In preterm infants, vitamin A availability is lower than in term neonates [82]. Clinically, vitamin A supplementation reduces mortality and oxygen requirement at 36 weeks and is therefore considered as a promising pharmacological intervention in BPD prevention [83]. Ongoing clinical trials try to increase availability of this therapy by testing alternative modes of delivery [84]. In animal models, various mechanisms of lung protection by vitamin $\mathrm{A}$ as decreased lung fibrosis and increased lung elastin expression have been described $[85,86]$. However, vitamin $\mathrm{A}$ is another example how therapeutic interventions depend on prenatal conditions. In a sheep model, intraamniotic exposure to inflammation reduced vitamin $\mathrm{A}$ in the lung [87], indicating that therapeutic benefit depends on the presence or absence of prenatal inflammation.

\section{Summary}

The developing lung of the preterm infant is pre-, peri-, and postnatally exposed to different stress factors, and their impact depends on interaction between different insults and interventions. Prenatal exposure to chorioamnionitis preconditions the lung to postnatal stressors, by, e.g., immunological compromise and early disturbance of pulmonary developmental pathways. Understanding the interaction between two or more "hits" is a prerequisite for understanding mechanisms of permanent lung injury in preterm infants and for individualization of therapeutic interventions in order to promote recovery from the stressors. There is, e.g., evidence that maternal glucocorticoids should be given to all women at risk of impending preterm birth [18], even in the presence of clinical chorioamnionitis. Experimentally, the timing of steroid treatment in relation to the onset or the already existing chorioamnionitis made a difference. Information on the exposure of the baby to chorioamnionitis may therefore 
be of interest for clinical decision-making. Since chorioamnionitis is clinically silent in most instances, and histologic analysis of the placenta takes considerably long, a prediction model based on clinical parameters which are available upon delivery might support clinical decisionmaking [88]. Beside inflammation, intrauterine growth restriction (IUGR) has been linked to fetal lung injury and poor development [89], and infants suffering from IUGR had an increased BPD risk in a cohort study [90]. The genetic background might be another factor priming the lung towards temporary or permanent lung injury [91]. Therefore, detailed knowledge of the prenatal situation is absolutely essential to predict postnatal lung development.

Consequently, postnatal interventions need to be tailored individually to help the lung recover from early stress without causing more interventional stress than absolutely necessary. These might include early medication and oxygen treatment as discussed above but also other factors like adequate functional residual capacity (FRC) [92] and perinatal procedures like delayed cord clamping [93] and less invasive surfactant therapy [65] or the choice of a surfactant resistant to inactivation [94]. The mechanisms behind the influence of nutrition like the positive effect of exclusive breast feeding on BPD incidence [95] need to be further elucidated, and the full potential of known pharmacologic interventions like vitamin A supplementation needs to be explored. The knowledge of the combined effects of prenatal situation and postnatal interventions can help to further optimize potentially stressful therapeutic interventions and support lung recovery of preterm infants based on biology and increasing clinical evidence.

\section{Competing interests}

The authors declare that they have no competing interests.

\section{Authors' contributions}

$\mathrm{MH}, \mathrm{TW}$, and BK drafted the manuscript, revised the manuscript critically, and gave final approval of the manuscript to be published.

\section{Author details \\ ${ }^{1}$ Neonatology, Department of Pediatrics, Maastricht University Medical Center, Maastricht, Netherlands. ${ }^{2}$ Neonatology, Department of Pediatrics, Aachen University Hospital, Aachen, Germany. ${ }^{3}$ Neonatology, Department of Pediatrics, Würzburg University Hospital, Würzburg, Germany. ${ }^{4}$ Faculty of Health, Medicine and Lifesciences, School for Oncology and Developmental Biology, Maastricht University, Maastricht, The Netherlands.}

Received: 29 December 2015 Accepted: 22 March 2016

Published online: 13 April 2016

\section{References}

1. Moss TJ (2006) Respiratory consequences of preterm birth. Clin Exp Pharmacol Physiol 33(3):280-284. doi:10.1111/j.1440-1681.2006.04359.x

2. Albertine $\mathrm{KH}$ (2013) Progress in understanding the pathogenesis of BPD using the baboon and sheep models. Semin Perinatol 37(2):60-68. doi:10.1053/.jsemperi.2013.01.001

3. Hutten MC, Kramer BW (2014) Patterns and etiology of acute and chronic lung injury: insights from experimental evidence. Zhongguo Dang Dai Er Ke Za Zhi 16(5):448-459
4. Horvath B, Lakatos F, Toth C, Bodecs T, Bodis J (2014) Silent chorioamnionitis and associated pregnancy outcomes: a review of clinical data gathered over a 16-year period. J Perinat Med 42(4):441-447. doi:10.1515/jpm-2013-0186

5. Abman SH, Conway SJ (2014) Developmental determinants and changing patterns of respiratory outcomes after preterm birth. Birth Defects Res A Clin Mol Teratol 100(3):127-133. doi:10.1002/bdra.23242

6. Kunzmann S, Collins JJ, Kuypers E, Kramer BW (2013) Thrown off balance: the effect of antenatal inflammation on the developing lung and immune system. Am J Obstet Gynecol 208(6):429-437. doi:10.1016/j.ajog.2013.01.008

7. Lahra MM, Beeby PJ, Jeffery HE (2009) Maternal versus fetal inflammation and respiratory distress syndrome: a 10-year hospital cohort study. Arch Dis Child Fetal Neonatal Ed 94(1):F13-F16. doi:10.1136/adc.2007.135889

8. Jobe AH (2012) What is RDS in 2012? Early Hum Dev 88(Suppl 2):S42-S44. doi:10.1016/50378-3782(12)70013-0

9. Been JV, Rours IG, Kornelisse RF, Jonkers F, de Krijger RR, Zimmermann LJ (2010) Chorioamnionitis alters the response to surfactant in preterm infants. J Pediatr 156(1):10-15. doi:10.1016/j.jpeds.2009.07.044, e11

10. Watterberg KL, Demers LM, Scott SM, Murphy S (1996) Chorioamnionitis and early lung inflammation in infants in whom bronchopulmonary dysplasia develops. Pediatrics 97(2):210-215

11. Van Marter L, Dammann O, Allred EN, Leviton A, Pagano M, Moore M, Martin C (2002) Chorioamnionitis, mechanical ventilation, and postnatal sepsis as modulators of chronic lung disease in preterm infants. J Pediatr 140(2):171-176. doi:10.1067/mpd.2002.121381

12. Been JV, Zimmermann $L J(2009)$ Histological chorioamnionitis and respiratory outcome in preterm infants. Arch Dis Child Fetal Neonatal Ed 94(3):F218-F225. doi:10.1136/adc.2008.150458

13. Moss TJ, Newnham JP, Willett KE, Kramer BW, Jobe AH, Ikegami M (2002) Early gestational intra-amniotic endotoxin: lung function, surfactant, and morphometry. Am J Respir Crit Care Med 165(6):805-811. doi:10.1164/ ajrccm.165.6.2108053

14. Yamada N, Sato Y, Moriguchi-Goto S, Yamashita A, Kodama Y, Sameshima H, Asada $Y$ (2015) Histological severity of fetal inflammation is useful in predicting neonatal outcome. Placenta 36(12):1490-1493. doi:10.1016/j. placenta.2015.10.021

15. Kallapur SG, Kramer BW, Knox CL, Berry CA, Collins JJ, Kemp MW, Nitsos I, Polglase GR, Robinson J, Hillman NH, Newnham JP, Chougnet C, Jobe AH (2011) Chronic fetal exposure to Ureaplasma parvum suppresses innate immune responses in sheep. J Immunol 187(5):2688-2695. doi:10.4049/ jimmunol.1100779

16. Kramer BW, Jobe AH (2005) The clever fetus: responding to inflammation to minimize lung injury. Biol Neonate 88(3):202-207. doi:10.1159/000087583

17. van de Laar R, van der Ham DP, Oei SG, Willekes C, Weiner CP, Mol BW (2009) Accuracy of $\mathrm{C}$-reactive protein determination in predicting chorioamnionitis and neonatal infection in pregnant women with premature rupture of membranes: a systematic review. Eur J Obstet Gynecol Reprod Biol 147(2): 124-129. doi:10.1016/j.jogrb.2009.09.017

18. Been JV, Degraeuwe PL, Kramer BW, Zimmermann $\sqcup$ (2011) Antenatal steroids and neonatal outcome after chorioamnionitis: a meta-analysis. Bjog 118(2):113-122. doi:10.1111/j.1471-0528.2010.02751.x

19. Roberts D, Dalziel S (2006) Antenatal corticosteroids for accelerating fetal lung maturation for women at risk of preterm birth. Cochrane Database Syst Rev 3:CD004454. doi:10.1002/14651858.CD004454.pub2

20. Kemp MW, Newnham JP, Challis JG, Jobe AH, Stock SJ (2015) The clinical use of corticosteroids in pregnancy. Hum Reprod Update. doi:10.1093/ humupd/dmv047

21. Brownfoot FC, Gagliardi DI, Bain E, Middleton P, Crowther CA (2013) Different corticosteroids and regimens for accelerating fetal lung maturation for women at risk of preterm birth. Cochrane Database Syst Rev 8:CD006764. doi:10.1002/ 14651858.CD006764.pub3

22. Effect of corticosteroids for fetal maturation on perinatal outcomes (1995) $\mathrm{NIH}$ Consensus Development Panel on the effect of corticosteroids for fetal maturation on perinatal outcomes. JAMA 273(5):413-418

23. Collins JJ, Kunzmann S, Kuypers E, Kemp MW, Speer CP, Newnham JP, Kallapur SG, Jobe AH, Kramer BW (2013) Antenatal glucocorticoids counteract LPS changes in TGF-beta pathway and caveolin-1 in ovine fetal lung. Am J Physiol Lung Cell Mol Physiol 304(6):L438-L444. doi:10.1152/ ajplung.00251.2012

24. Collins JJ, Kuypers E, Nitsos I, Jane Pillow J, Polglase GR, Kemp MW, Newnham JP, Cleutjens JP, Frints SG, Kallapur SG, Jobe AH, Kramer BW (2012) LPS-induced chorioamnionitis and antenatal corticosteroids 
modulate Shh signaling in the ovine fetal lung. Am J Physiol Lung Cell Mol Physiol 303(9):L778-L787. doi:10.1152/ajplung.00280.2011

25. Kuypers E, Collins JJ, Kramer BW, Ofman G, Nitsos I, Pillow JJ, Polglase GR, Kemp MW, Newnham JP, Gavilanes AW, Nowacki R, Ikegami M, Jobe AH, Kallapur SG (2012) Intra-amniotic LPS and antenatal betamethasone: inflammation and maturation in preterm lamb lungs. Am J Physiol Lung Cell Mol Physiol 302(4):L380-L389. doi:10.1152/ajplung.00338.2011

26. Saugstad OD (2001) Update on oxygen radical disease in neonatology. Curr Opin Obstet Gynecol 13(2):147-153

27. Cheah FC, Jobe AH, Moss TJ, Newnham JP, Kallapur SG (2008) Oxidative stress in fetal lambs exposed to intra-amniotic endotoxin in a chorioamnionitis model. Pediatr Res 63(3):274-279. doi:10.1203/PDR. 0b013e31815f653b

28. Sosenko IR, Jobe AH (2003) Intraamniotic endotoxin increases lung antioxidant enzyme activity in preterm lambs. Pediatr Res 53(4):679-683. doi:10.1203/01.PDR.0000055769.19891.C4

29. Kramer BW, Kallapur S, Newnham J, Jobe AH (2009) Prenatal inflammation and lung development. Semin Fetal Neonatal Med 14(1):2-7. doi:10.1016/j. siny.2008.08.011.

30. Speer CP (2006) Inflammation and bronchopulmonary dysplasia: a continuing story. Semin Fetal Neonatal Med 11(5):354-362. doi:10.1016/j. siny. 2006.03 .004

31. Buonocore G, Perrone S, Tataranno ML (2010) Oxygen toxicity: chemistry and biology of reactive oxygen species. Semin Fetal Neonatal Med 15(4): 186-190. doi:10.1016/j.siny.2010.04.003

32. Kallapur SG, Kramer BW, Moss TJ, Newnham JP, Jobe AH, Ikegami M, Bachurski CJ (2003) Maternal glucocorticoids increase endotoxin-induced lung inflammation in preterm lambs. Am J Physiol Lung Cell Mol Physiol 284(4):L633-L642. doi:10.1152/ajplung.00344.2002

33. Walther FJ, Jobe AH, Ikegami M (1998) Repetitive prenatal glucocorticoid therapy reduces oxidative stress in the lungs of preterm lambs. J Appl Physiol 85(1):273-278

34. Stark MJ, Hodyl NA, Wright IM, Clifton VL (2011) Influence of sex and glucocorticoid exposure on preterm placental pro-oxidant-antioxidant balance. Placenta 32(11):865-870. doi:10.1016/j.placenta.2011.08.010

35. Vento M, Aguar M, Escobar J, Arduini A, Escrig R, Brugada M, Izquierdo I, Asensi MA, Sastre J, Saenz P, Gimeno A (2009) Antenatal steroids and antioxidant enzyme activity in preterm infants: influence of gender and timing. Antioxid Redox Signal 11(12):2945-2955. doi:10.1089/ars.2009.2671

36. Verhaeghe J, van Bree R, Van Herck E (2009) Oxidative stress after antenatal betamethasone: acute downregulation of glutathione peroxidase-3. Early Hum Dev 85(12):767-771. doi:10.1016/j.earlhumdev.2009.10.005

37. Kramer BW, Kallapur S, Jobe A (2014) Chorioamnionitis and oxidative stress-new ideas from experimental models. In: Dennery PA, Buonocore G, Saugstad OD (eds) Studies on Perinatal \& Prenatal Disorders. Springer, New York

38. Maltepe E, Saugstad OD (2009) Oxygen in health and disease: regulation of oxygen homeostasis-clinical implications. Pediatr Res 65(3):261-268. doi:10.1203/PDR.0b013e31818fc83f

39. Friel JK, Friesen RW, Harding SV, Roberts LJ (2004) Evidence of oxidative stress in full-term healthy infants. Pediatr Res 56(6):878-882. doi:10.1203/01. PDR.0000146032.98120.43

40. Finer $\mathrm{N}$, Rich W (2010) Neonatal resuscitation for the preterm infant: evidence versus practice. J Perinatol 30(Suppl):S57-S66. doi:10.1038/jp.2010.115

41. Obladen M (2009) History of neonatal resuscitation. Part 2: oxygen and other drugs. Neonatology 95(1):91-96. doi:10.1159/000151761

42. Saugstad OD, Rootwelt T, Aalen O (1998) Resuscitation of asphyxiated newborn infants with room air or oxygen: an international controlled trial: the Resair 2 study. Pediatrics 102(1):e1

43. Dawson JA, Kamlin CO, Vento M, Wong C, Cole TJ, Donath SM, Davis PG, Morley CJ (2010) Defining the reference range for oxygen saturation for infants after birth. Pediatrics 125(6):e1340-e1347. doi:10.1542/ peds.2009-1510

44. Saugstad OD, Aune D, Aguar M, Kapadia V, Finer N, Vento M (2014) Systematic review and meta-analysis of optimal initial fraction of oxygen levels in the delivery room at $</=32$ weeks. Acta Paediatr 103(7):744-751. doi:10.1111/apa.12656

45. Vento M, Moro M, Escrig R, Arruza L, Villar G, lzquierdo I, Roberts $L J$ 2nd, Arduini A, Escobar JJ, Sastre J, Asensi MA (2009) Preterm resuscitation with low oxygen causes less oxidative stress, inflammation, and chronic lung disease. Pediatrics 124(3):e439-e449. doi:10.1542/peds.2009-0434
46. Kapadia VS, Chalak LF, Sparks JE, Allen JR, Savani RC, Wyckoff MH (2013) Resuscitation of preterm neonates with limited versus high oxygen strategy. Pediatrics 132(6):e1488-e1496. doi:10.1542/peds.2013-0978

47. Jobe AH, Hillman N, Polglase G, Kramer BW, Kallapur S, Pillow J (2008) Injury and inflammation from resuscitation of the preterm infant. Neonatology 94(3):190-196. doi:10.1159/000143721

48. Vento M, Aguar M, Brugada M, Escobar J, Escrig R, Cubells E, Cernada M (2012) Oxygen saturation targets for preterm infants in the delivery room. J Matern Fetal Neona 25(Suppl 1):45-46. doi:10.3109/14767058.2012.663175

49. Vento M (2014) Oxygen supplementation in the neonatal period: changing the paradigm. Neonatology 105(4):323-331. doi:10.1159/000360646

50. Wyllie J, Perlman JM, Kattwinkel J, Wyckoff MH, Aziz K, Guinsburg R, Kim HS, Liley HG, Mildenhall L, Simon WM, Szyld E, Tamura M, Velaphi S (2015) Part 7: Neonatal resuscitation: 2015 International Consensus on Cardiopulmonary Resuscitation and Emergency Cardiovascular Care Science with Treatment Recommendations. Resuscitation 95:e169-e201. doi:10.1016/j.resuscitation. 2015.07.045

51. Maxwell LG, Harris AP, Sendak MJ, Donham RT (1987) Monitoring the resuscitation of preterm infants in the delivery room using pulse oximetry. Clin Pediatr (Phila) 26(1):18-20

52. Goos TG, Rook D, van der Eijk AC, Kroon AA, Pichler G, Urlesberger B, Dankelman J, Reiss IK (2013) Observing the resuscitation of very preterm infants: are we able to follow the oxygen saturation targets? Resuscitation 84(8):1108-1113. doi:10.1016/j.resuscitation.2013.01.025

53. Claure N, Bancalari E (2015) Closed-loop control of inspired oxygen in premature infants. Semin Fetal Neonatal Med 20(3):198-204. doi:10.1016/j. siny.2015.02.003

54. Hummler H, Fuchs H, Schmid M (2014) Automated adjustments of inspired fraction of oxygen to avoid hypoxemia and hyperoxemia in neonates-a systematic review on clinical studies. Klin Padiatr 226(4):204-210. doi:10.1055/s-0034-1375617

55. Hutten MC, Goos TG, Ophelders D, Nikiforou M, Kuypers E, Willems M, Niemarkt HJ, Dankelman J, Andriessen P, Mohns T, Reiss IK, Kramer BW (2015) Fully automated predictive intelligent control of oxygenation (PRICO) in resuscitation and ventilation of preterm lambs. Pediatr Res. doi:10.1038/pr.2015.158

56. Bjorklund LJ, Ingimarsson J, Curstedt T, John J, Robertson B, Werner O, Vilstrup CT (1997) Manual ventilation with a few large breaths at birth compromises the therapeutic effect of subsequent surfactant replacement in immature lambs. Pediatr Res 42(3):348-355. doi:10.1203/00006450199709000-00016

57. te Pas AB, Siew M, Wallace MJ, Kitchen MJ, Fouras A, Lewis RA, Yagi N, Uesugi K, Donath S, Davis PG, Morley CJ, Hooper SB (2009) Effect of sustained inflation length on establishing functional residual capacity at birth in ventilated premature rabbits. Pediatr Res 66(3):295-300. doi:10.1203/PDR.0b013e3181b1bca4

58. Hillman NH, Kemp MW, Noble PB, Kallapur SG, Jobe AH (2013) Sustained Inflation at birth did not protect preterm fetal sheep from lung injury. Am J Physiol Lung Cell Mol Physiol. doi:10.1152/ajplung.00162.2013

59. Lista G, Boni L, Scopesi F, Mosca F, Trevisanuto D, Messner H, Vento G, Magaldi R, Del Vecchio A, Agosti M, Gizzi C, Sandri F, Biban P, Bellettato M, Gazzolo D, Boldrini A, Dani C (2015) Sustained lung inflation at birth for preterm infants: a randomized clinical trial. Pediatrics 135(2):e457-e464. doi:10.1542/peds.2014-1692

60. Hillman NH, Kallapur SG, Pillow JJ, Moss TJ, Polglase GR, Nitsos I, Jobe AH (2010) Airway injury from initiating ventilation in preterm sheep. Pediatr Res 67(1):60-65. doi:10.1203/PDR.0b013e3181c1b09e

61. Bland RD, Xu L, Ertsey R, Rabinovitch M, Albertine KH, Wynn KA, Kumar VH, Ryan RM, Swartz DD, Csiszar K, Fong KSK (2007) Dysregulation of pulmonary elastin synthesis and assembly in preterm lambs with chronic lung disease. Am J Physiol Lung Cell Mol Physiol 292(6):L1370-L1384. doi:10.1152/ajplung. 00367.2006

62. Hillman NH, Pillow JJ, Ball MK, Polglase GR, Kallapur SG, Jobe AH (2009) Antenatal and postnatal corticosteroid and resuscitation induced lung injury in preterm sheep. Respir Res 10:124. doi:10.1186/1465-9921-10-124

63. Gopel W, Kribs A, Ziegler A, Laux R, Hoehn T, Wieg C, Siegel J, Avenarius S, von der Wense A, Vochem M, Groneck P, Weller U, Moller J, Hartel C, Haller S, Roth B, Herting E (2011) Avoidance of mechanical ventilation by surfactant treatment of spontaneously breathing preterm infants (AMV): an open-label, randomised, controlled trial. Lancet 378(9803):1627-1634. doi:10.1016/S01406736(11)60986-0 
64. Gittermann MK, Fusch C, Gittermann AR, Regazzoni BM, Moessinger AC (1997) Early nasal continuous positive airway pressure treatment reduces the need for intubation in very low birth weight infants. Eur J Pediatr 156(5):384-388

65. Gopel W, Kribs A, Hartel C, Avenarius S, Teig N, Groneck P, Olbertz D, Roll C, Vochem M, Weller $U$, von der Wense A, Wieg C, Wintgens J, Preuss M, Ziegler A, Roth B, Herting E (2015) Less invasive surfactant administration is associated with improved pulmonary outcomes in spontaneously breathing preterm infants. Acta Paediatr 104(3):241-246. doi:10.1111/apa.12883

66. Aranda JV, Beharry K, Valencia GB, Natarajan G, Davis J (2010) Caffeine impact on neonatal morbidities. J Matern Fetal Neona 23(Suppl 3):20-23. doi:10.3109/14767058.2010.517704

67. Schmidt B, Roberts RS, Davis P, Doyle LW, Barrington KJ, Ohlsson A, Solimano A, Tin W (2006) Caffeine therapy for apnea of prematurity. N Engl J Med 354(20):2112-2121. doi:10.1056/NEJMoa054065

68. Bauer J, Maier K, Linderkamp O, Hentschel R (2001) Effect of caffeine on oxygen consumption and metabolic rate in very low birth weight infants with idiopathic apnea. Pediatrics 107(4):660-663

69. Dobson NR, Patel RM, Smith PB, Kuehn DR, Clark J, Vyas-Read S, Herring A, Laughon MM, Carlton D, Hunt CE (2014) Trends in caffeine use and association between clinical outcomes and timing of therapy in very low birth weight infants. J Pediatr 164(5):992-998. doi:10.1016/j.jpeds.2013.12.025, e993

70. Henderson-Smart DJ, Davis PG (2010) Prophylactic methylxanthines for endotracheal extubation in preterm infants. Cochrane Database Syst Rev 12: CD000139. doi:10.1002/14651858.CD000139.pub2

71. Alur P, Bollampalli V, Bell T, Hussain N, Liss J (2015) Serum caffeine concentrations and short-term outcomes in premature infants of 29 weeks of gestation. J Perinatol 35(6):434-438. doi:10.1038/jp.2014.226

72. Dobson NR, Hunt CE (2013) Pharmacology review: caffeine use in neonates: indications, pharmacokinetics, clinical effects, outcomes. NeoReviews 14: e540. doi:10.1542/neo.14-11-e540

73. Chavez Valdez R, Ahlawat R, Wills-Karp M, Nathan A, Ezell T, Gauda EB (2011) Correlation between serum caffeine levels and changes in cytokine profile in a cohort of preterm infants. J Pediatr 158(1):57-64. doi:10.1016/j.jpeds. 2010.06.051, 64 e51

74. Davis PG, Schmidt B, Roberts RS, Doyle LW, Asztalos E, Haslam R, Sinha S, Tin W (2010) Caffeine for Apnea of Prematurity trial: benefits may vary in subgroups. J Pediatr 156(3):382-387. doi:10.1016/j.jpeds.2009.09.069

75. Patel RM, Leong T, Carlton DP, Vyas-Read S (2013) Early caffeine therapy and clinical outcomes in extremely preterm infants. J Perinatol 33(2):134-140. doi:10.1038/jp.2012.52

76. Martin RJ, Fanaroff AA (2013) The preterm lung and airway: past, present, and future. Pediatr Neonatol 54(4):228-234. doi:10.1016/j. pedneo.2013.03.001

77. Fehrholz M, Hutten M, Kramer BW, Speer CP, Kunzmann S (2014) Amplification of steroid-mediated SP-B expression by physiological levels of caffeine. Am J Physiol Lung Cell Mol Physiol 306(1):L101-L109. doi:10.1152/ajplung.00257.2013

78. Fehrholz M, Bersani I, Kramer BW, Speer CP, Kunzmann S (2012) Synergistic effect of caffeine and glucocorticoids on expression of surfactant protein B (SP-B) mRNA. PLoS ONE 7(12):e51575. doi:10.1371/journal.pone.0051575

79. Katheria AC, Sauberan JB, Akotia D, Rich W, Durham J, Finer NN (2015) A pilot randomized controlled trial of early versus routine caffeine in extremely premature infants. Am J Perinatol 32(9):879-886. doi:10.1055/s-0034-1543981

80. Massaro D, Massaro GD (2003) Retinoids, alveolus formation, and alveolar deficiency: clinical implications. Am J Respir Cell Mol Biol 28(3):271-274. doi:10.1165/rcmb.F263

81. Biesalski HK (2003) The significance of vitamin A for the development and function of the lung. Forum Nutr 56:37-40

82. Ambalavanan N, Wu TJ, Tyson JE, Kennedy KA, Roane C, Carlo WA (2003) A comparison of three vitamin A dosing regimens in extremely-low-birthweight infants. J Pediatr 142(6):656-661. doi:10.1067/mpd.2003.214

83. Darlow BA, Graham PJ (2011) Vitamin A supplementation to prevent mortality and short- and long-term morbidity in very low birthweight infants. Cochrane Database Syst Rev 10:CD000501. doi:10.1002/14651858. CD000501.pub3

84. Meyer S, Kronfeld K, Graber S, Butzer R, Wahl H, Gortner L (2013) Vitamin A to prevent bronchopulmonary dysplasia: the NeoVitaA trial. J Matern Fetal Neona 26(5):544-545. doi:10.3109/14767058.2012.745499

85. Ozer EA, Kumral A, Ozer E, Duman N, Yilmaz O, Ozkal S, Ozkan H (2005) Effect of retinoic acid on oxygen-induced lung injury in the newborn rat. Pediatr Pulmonol 39(1):35-40. doi:10.1002/ppul.20131
86. Pierce RA, Joyce B, Officer S, Heintz C, Moore C, McCurnin D, Johnston C, Maniscalco W (2007) Retinoids increase lung elastin expression but fail to alter morphology or angiogenesis genes in premature ventilated baboons. Pediatr Res 61(6):703-709. doi:10.1203/pdr.0b013e318053661d

87. Kramer BW, Albertine KH, Moss TJ, Nitsos I, Ladenburger A, Speer CP, Newnham JP, Jobe AH (2008) All-trans retinoic acid and intra-amniotic endotoxin-mediated effects on fetal sheep lung. Anat Rec (Hoboken) 291(10):1271-1277. doi:10.1002/ar.20743

88. Been JV, Vanterpool SF, de Rooij JD, Rours GI, Kornelisse RF, van Dongen MC, van Gool CJ, de Krijger RR, Andriessen P, Zimmermann LJ, Kramer BW (2012) A clinical prediction rule for histological chorioamnionitis in preterm newborns. PLOS ONE 7(10):e46217. doi:10.1371/journal.pone.0046217

89. Mestan KK, Steinhorn RH (2011) Fetal origins of neonatal lung disease: understanding the pathogenesis of bronchopulmonary dysplasia. Am J Physiol Lung Cell Mol Physiol 301(6):L858-L859. doi:10.1152/ajplung.00314.2011

90. Eriksson L, Haglund B, Odlind V, Altman M, Ewald U, Kieler H (2015) Perinatal conditions related to growth restriction and inflammation are associated with an increased risk of bronchopulmonary dysplasia. Acta Paediatr 104(3):259-263. doi:10.1111/apa.12888

91. Lal CV, Ambalavanan N (2015) Genetic predisposition to bronchopulmonary dysplasia. Semin Perinatol 39(8):584-591. doi:10.1053/j.semperi.2015.09.004

92. Hooper SB, Harding R (2005) Role of aeration in the physiological adaptation of the lung to air-breathing at birth. Curr Resp Med Rev 1:185-195

93. Valero J, Desantes D, Perales-Puchalt A, Rubio J, Diago Almela VJ, Perales A (2012) Effect of delayed umbilical cord clamping on blood gas analysis. Eur J Obstet Gynecol Reprod Biol 162(1):21-23. doi:10.1016/j.ejogrb.2012.01.020

94. Seehase M, Collins JJ, Kuypers E, Jellema RK, Ophelders DR, Ospina OL, Perez-Gil J, Bianco F, Garzia R, Razzetti R, Kramer BW (2012) New surfactant with SP-B and $C$ analogs gives survival benefit after inactivation in preterm lambs. PLoS ONE 7(10):e47631. doi:10.1371/journal.pone.0047631

95. Spiegler J, Preuss M, Gebauer C, Bendiks M, Herting E, Gopel W (2016) Does breastmilk influence the development of bronchopulmonary dysplasia? J Pediatr 169(76-80):e74. doi:10.1016/j.jpeds.2015.10.080

\section{Submit your manuscript to a SpringerOpen ${ }^{\circ}$ journal and benefit from:}

- Convenient online submission

- Rigorous peer review

- Immediate publication on acceptance

- Open access: articles freely available online

- High visibility within the field

- Retaining the copyright to your article

Submit your next manuscript at $>$ springeropen.com 